\title{
The Woods around the Ivory Tower: A Systematic Review Examining the Value and Relevance of School Forests in the United States
}

\author{
Kimberly J. Coleman ${ }^{1,2, *}$, Elizabeth E. Perry ${ }^{2,3}{ }^{(0)}$, Dominik Thom ${ }^{2,4,5,6} \oplus^{\circ}$, \\ Tatiana M. Gladkikh ${ }^{2,4}{ }^{\circ}$, William S. Keeton ${ }^{2,4}$, Peter W. Clark ${ }^{2}$, Ralph E. Tursini Jr. ${ }^{2}$ \\ and Kimberly F. Wallin 2,7 \\ 1 Center for Earth and Environmental Science, State University of New York at Plattsburgh, \\ Plattsburgh, NY 12901, USA \\ 2 Rubenstein School of Environment and Natural Resources, University of Vermont, \\ Burlington, VT 05405, USA; Dominik.Thom@uvm.edu (D.T.); tgladkik@uvm.edu (T.M.G.); \\ William.keeton@uvm.edu (W.S.K.); peter.clark@uvm.edu (P.W.C.); ralph.tursini@uvm.edu (R.E.T.J.); \\ kwallin@uvm.edu (K.F.W.) \\ 3 Department of Parks, Recreation, and Tourism Management, Clemson University, \\ Clemson, SC 29634-0735, USA; eeperry@clemson.edu \\ 4 Gund Institute for Environment, University of Vermont, Burlington, VT 05405, USA \\ 5 Institute of Silviculture, Department of Forest- and Soil Sciences, University of Natural Resources and Life \\ Sciences (BOKU) Vienna, 1190 Vienna, Austria \\ 6 Ecosystem Dynamics and Forest Management Group, School of Life Sciences, \\ Technical University of Munich, 85354 Freising, Germany \\ 7 USDA Forest Service Northern Research Station, South Burlington, VT 05403, USA \\ * Correspondence: kcole014@plattsburgh.edu
}

Received: 15 December 2019; Accepted: 6 January 2020; Published: 10 January 2020

\begin{abstract}
Throughout the United States, many institutions of higher education own forested tracts, often called school forests, which they use for teaching, research, and demonstration purposes. These school forests provide a range of benefits to the communities in which they are located. However, because administration is often decoupled from research and teaching, those benefits might not always be evident to the individuals who make decisions about the management and use of school forests, which may undervalue their services and put these areas at risk for sale, development, or over-harvesting to generate revenue. To understand what messages are being conveyed about the value and relevance of school forests, we conducted a systematic literature review and qualitatively coded the resulting literature content using an ecosystem services framework. While school forests provide many important benefits to academic and local communities, we found that most of the existing literature omits discussions about cultural ecosystem services that people may receive from school forests. We discuss the implications of this omission and make recommendations for addressing it.
\end{abstract}

Keywords: cultural ecosystem services; school forests; community forestry; forest planning and management; higher education; relevance

\section{Introduction}

School forests are increasingly threatened by financial concerns of institutions of higher education (IHE). School forests are wooded tracts owned or managed by a college or university [1], henceforth referred to as an IHE. Within the U.S., these forests provide critical benefits, including opportunities for hands-on education for undergraduate students, graduate students, and community members; research 
sites for a wide range of scholars; opportunities for recreation for members of the IHE community and broader community; spaces to demonstrate new techniques or guidelines in forest management and timber harvesting; and a host of other benefits [2,3].

However, these benefits may not be clear to those who do not interact directly with school forests. Furthermore, recent stories, such as plans to develop Virginia Tech's Stadium Woods into an indoor athletic training facility [4] and the University of Mississippi debate about leasing its school forest to logging companies to generate revenue [5], call into question whether school forests are viewed as valuable and relevant to broad communities. Additionally, an increasing number of forestry and forest science programs are facing reorganization within their home IHE and, subsequently, a loss of control over their budgets and resources [6]. These trends suggest that school forests may be at increasing risk of sale and development. This leads to a concern that if school forests are not viewed as valuable and relevant to IHE and community members alike, economic risks may continue to increase.

The academic literature is one of the primary information sources for those individuals who make decisions about the management of school forests, because these individuals are often current/former academics. Thus, if we understand how school forests are described in the literature, we may begin to understand how decision makers value them. We conducted a systematic literature review to understand how U.S. school forests are valued and how these values are expressed in academic literature. This manuscript reports on the results of that review and provides a discussion on the relevance of school forests.

While it is common for IHEs worldwide to own other types of natural areas and facilities as well, such as botanical gardens and agricultural lands, we focus this paper on school forests in the U.S. for two reason. First, the creation of school forests in the U.S. grew out of a common history and thus many forests share common missions, which we detail in the body of this paper. Second, as mentioned above, recent trends suggest that school forests may be at risk for sale and development, a trend that we have not observed for facilities like botanical gardens. Our findings will be of interest to those managing school forests in the U.S. They will also be useful to managers of school forests, forested parks, and other protected areas around the globe, as we provide recommendations for policies and practices to increase relevance and, subsequently, support for similar forested areas.

\section{Background}

\subsection{Ecosystem Services Framework}

The ecosystem services (ESs) framework is a useful tool for thinking about the benefits that are provided by ecosystems, including school forests, to society [7]. ESs are defined as the characteristics and processes of a given natural environment that support human life [8]. Broadly speaking, research on ESs provided by forests has focused heavily on biophysical services [9], with substantially less emphasis placed on cultural ecosystem services (CESs) [10]. CESs are defined as the "non-material benefits that people derive from human-ecological relations" [11] (p. 206). Biophysical services are often categorized as provisioning, regulating, and supporting services [7] and include services like food production, climate regulation, and nutrient cycling. Although there is consensus that biophysical services are organized into the three aforementioned categories, there is less agreement about what counts as a CES. A review of 10 typologies of CESs revealed the most commonly discussed services: aesthetics, artistic inspiration, bequest, cultural diversity, cultural heritage, education, existence, identity, knowledge systems, recreation, sense of place, social capital, and spirituality [12]. As with most natural areas, school forests are likely to provide a wide range of ESs, both biophysical and cultural. We discuss some ESs widely attributed to school forests in the sections below.

\subsection{School Forests and the Ecosystems Services They Provide}

School forests have a long history in the U.S., dating to the 1898 founding of the first professional school of forestry, the New York State College of Forestry at Cornell University $[13,14]$. This first school 
of forestry was later moved and renamed the State University of New York, School of Environmental Science and Forestry at Syracuse. Its associated school forest consisted of 30,000 acres in the newly created Adirondack State Park and was intended to be used to both introduce students to "practical forest work" and to serve as a research site for "experiments in forestry methods" [15] (p. 31). Since that time, forestry programs at IHEs have been established nationwide, many with associated school forests. Today, many IHEs own one or more school forests, particularly if the institution has a forestry program $[1,16]$.

Most school forests adopted missions similar to the first school forest at Cornell and served as outdoor laboratories for research, field-based education, and demonstration [16]. For example, when Harvard Forest was founded in 1907, its goals were to serve as "field laboratory for students; a research center in forestry and related disciplines, including soils, wildlife biology, geography and botany; and a demonstration of practical sustained forestry" [17]. Similarly, when the University of California Berkeley's School of Forestry established policies for its Blodgett Forest in 1934, it stated the forest should be used primarily for research, but also for graduate education and as a demonstration site appealing "to both industrial lumberman and owners of woodlots" [18] (p. 739). Thus, these early articulations of purpose acknowledged that school forests provided the ESs of research and education, as well as the potential relevance of these forests to audiences beyond the IHE community.

Today, many school forests explicitly include multiple goals, stakeholders, and audiences, commonly with a three-pronged mission of research, teaching, and demonstration [1]. Given that commonly articulated mission [1], it is perhaps unsurprising that one of the major ESs provided by school forests, arguably the ES most often associated with school forests is as a research site $[1,16]$. Harvard Forest, for example, was the site of foundational work that explored the impact of land use [19] and natural disturbance [20] on New England forests. The site continues to provide researchers with a location for critical investigations covering a wide swath of disciplines biodiversity studies; conservation and management; ecological informatics and modeling; climate and carbon exchange; historical and retrospective studies; invasive plants, pests, and pathogens; physiological ecology, population dynamics, and species interactions; soil carbon and nitrogen dynamics; and watershed ecology [17]. Harvard Forest is one of many examples of how school forests provide laboratories for scientists to pursue pressing questions across a range of disciplines. The research outputs produced at school forests represent valuable contributions to the scientific community.

Another ES commonly associated with school forests is education, through both the teaching of undergraduate and graduate students as well as demonstrations for landowners and forestry practitioners $[1,16]$. For example, The University of Vermont's Jericho Research Forest plays a critical role in forestry education because it functions as a research site for graduate students conducting thesis and dissertation work and it provides an opportunity for students to observe/practice forestry techniques and skills [3]. Fulfilling the triad mission of research, teaching, and demonstration, this forest also hosts multiple silvicultural research and demonstration sites [21]. The University of Idaho's forest is among many with a long history of providing similar opportunities to students [2]. Both forests engage in demonstration activities designed to share new forestry techniques or emerging science with forest landowners and forestry professionals [2,3]. In addition to their role in supporting research, school forests play an important role in the training of current and future forestry professionals.

Although it is not always articulated in their missions, school forests provide a wide array of biophysical ESs. For example, after the University of Florida acquired the Austin Cary Memorial Forest, managers noted that the mature stands of longleaf pine (Pinus palustris) were providing habitat for the federally endangered red-cockaded woodpecker (Picoides borealis) [22]. As a second example, The Ecosystems Conservancy cited the University of Mississippi's school forest as one of the most important remaining examples of old-growth longleaf pine forest [5]. A 1985 census of accredited forestry programs showed that 44 IHEs owned, at that time, a collective quarter-million acres of land in the form of school forests [16]. This sheer area suggests that school forests represent an important subset of public U.S. forested lands with a potential range of biophysical ESs. 


\subsection{Relevance of School Forests}

The idea of relevance provides a lens through which to examine how school forests might be perceived by IHEs and broader community groups, regardless of the ESs that they provide. Relevance is a mercurial concept. However, it is solidly an increasingly imperative focus in conservation programs and forest management [23-26]. Despite the benefits discussed above, there have long been questions about school forests' relevance to local communities. Indeed, the New York State College of Forestry was defunded after only a few years in large due to public outcry regarding the management of Cornell's school forest in the Adirondacks. A 1905 paper published in the Journal of Forestry states [15] (p. 36):

The complaints of influential adjoiners regarding this so-called forest devastation, the illegal use of state forests, and the damage to their hunting interest increased. Appreciation of rational forest treatment and of slow growth of values which is characteristic of all forest management, calling for sacrifices in the present in favor of a future, is altogether but little developed in the United States.

More recently, a number of schools have grappled with selling school forests. In 1995, the University of Mississippi considered leasing its school forest to logging companies to generate revenue [5]. Virginia Tech and Clemson University considered utilizing school forests for development in recent years $[1,4]$. In all three cases, public opposition from community members who viewed the forests as a public good stopped large-scale commercial harvests or proposed disposal (i.e., sale) of the properties for development $[1,4,5]$. Public perception about school forests matters: it may lead community groups to advocate against or for forests' protection [1].

Because considerations of the audience for and the substance of relevance are diverse, investigations tend to center on a specific population, such as racial and ethnic minorities, local businesses, or youth groups [27-29]. A number of studies about relevance have focused on specific aspects similar to CESs, such as connections to economic vitality, spiritual connection, or health/wellbeing [30-32]. In this regard, the CES framework provides a succinct (though certainly not exhaustive) listing of aspects in which relevance could be established and strengthened with diverse audiences.

Relevance is important on a practical level, as greater relevance may lead to greater conservation advocacy. At its core are two fundamental tenets upon which managers can pursue action. The first is that relevance is a process whereby managers identify common goals with a target audience and take action toward these goals [33]. Thus, relevance necessitates managers understanding audiences and incorporating their perspectives. The second is that these relevance-driven managerial actions center on inclusive practices that broaden and deepen sites' and stories' resonance, usefulness, or applicability to people's own experiences and quality of life [34]. For example, broad connections may take the form of managers reaching multiple audiences with school forest programming and deep connections may entail creating multiple engagement points with an audience during that programming.

\section{Study Objectives}

CESs play a critical role in driving landowner decision making, motivating public engagement with forested areas, and informing land-use planning [35]. In the context of school forests, we theorize that CESs may engender broad and deep relevance. In particular, we posit that CESs, for example artistic inspiration, sense of place, and recreation, may lead to these connections and, subsequently, relevance. We hypothesize, however, that CESs are less documented in the academic literature about school forests.

The academic literature is a major information source for school administrators, i.e., those individuals making decisions about the future of school forests are steeped in academic culture and are likely to place a high value on academic literature and the messages it conveys. Therefore, the goal of this work was to explore the relevance of school forests, particularly as conveyed by sources likely to be consumed by those responsible for delegating institutional and departmental resources. Specifically, this paper explores how school forests are portrayed in the academic literature, and the prevalence and diversity of ESs attributed to school forests in particular. 


\section{Materials and Methods}

We conducted a systematic literature review [36-38] to understand how school forests in the U.S. are being portrayed and which ESs provided by school forests are being discussed within academic literature. We use the term "works" to describe the literature we reviewed, which included refereed publications, as well as books, theses and dissertations, conference proceedings, technical reports, and other relevant references. We included all these types of work in our review, recognizing that scientific works come in many publication formats. We, the research team, included faculty, graduate students, postdoctoral researchers, and one forest manager. Several of us have extensive experience working, learning, teaching, and researching at school forests, while others have limited or no experience at school forests. We represented a diversity of areas of expertise within forest-related natural and social sciences, and thus made up an interdisciplinary team. These various roles and expertise allowed us to examine the data from multiple perspectives and paradigms. To conduct the review, we collaboratively listed and agreed on sixteen search terms (below, with asterisks used as a wild card Boolean for alternate search term endings), which were each entered into three databases (Web of Science, Google Scholar, and Agricola):

1. "University-owned forest *"

2. "University-owned" + forest

3. "University-owned" + tract *

4. "University-owned" + "research forest"

5. "University-owned" + "research tract *"

6. "College-owned forest *"

7. "College-owned" + forest

8. "College-owned" + tract *

9. "College-owned" + "research forest"

10. "College-owned" + "research tract *"

11. "University research forest *"

12. "University research tract *"

13. "College research tract *"

14. "College research forest *"

15. "University forest *"

16. "College forest $*$

The search was conducted during the spring of 2018, and the review of works took place during the period May 10-June 10, 2018. We examined the first 200 search results for each term and, if results were in excess of 200, continued scanning through the results until finding a block of 50 irrelevant results in a row. The search results $(n=29,302)$ were then scanned for relevance to this investigation. A result was considered irrelevant and discarded if it did not mention a forest owned by an IHE, it described research conducted outside the U.S., and/or it did not provide an English translation. The search resulted in 176 academic works available for direct download. The search also uncovered an additional 31 works not available for direct download; we accessed these works through Interlibrary Loan. This total of 207 works was then further reviewed for relevance. Seventy-seven works were removed because they either did not focus directly on a school forest or because the research described took place outside of a U.S. state or territory. The final database contained 130 works, indicating that $63 \%$ of the potentially relevant works were deemed actually relevant to this investigation through the agreed upon standardized criteria for inclusion (Figure 1). These works represented 43 school forests across the continental U.S. (Figure 2). 


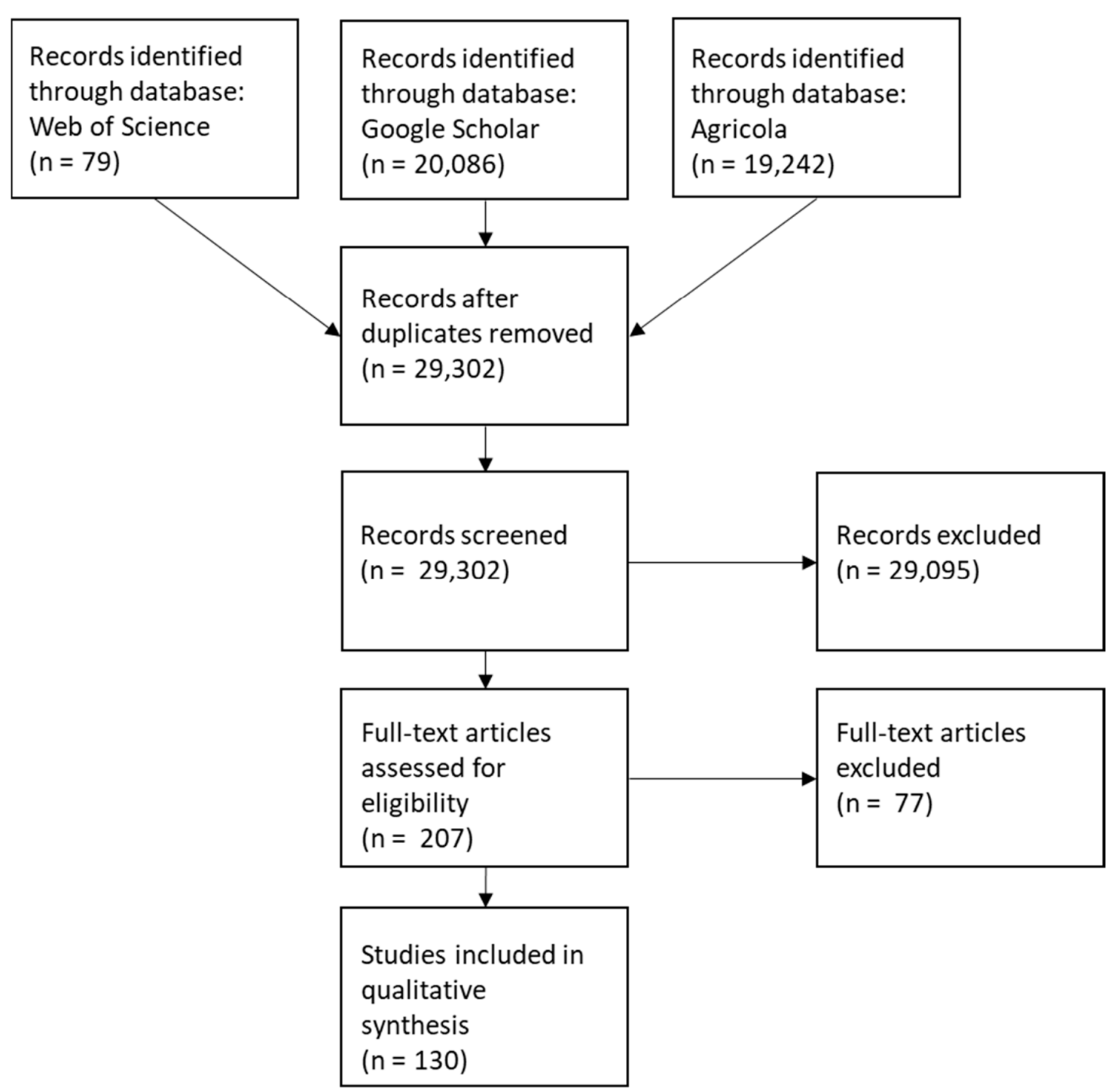

Figure 1. Steps followed to complete systematic literature review. 


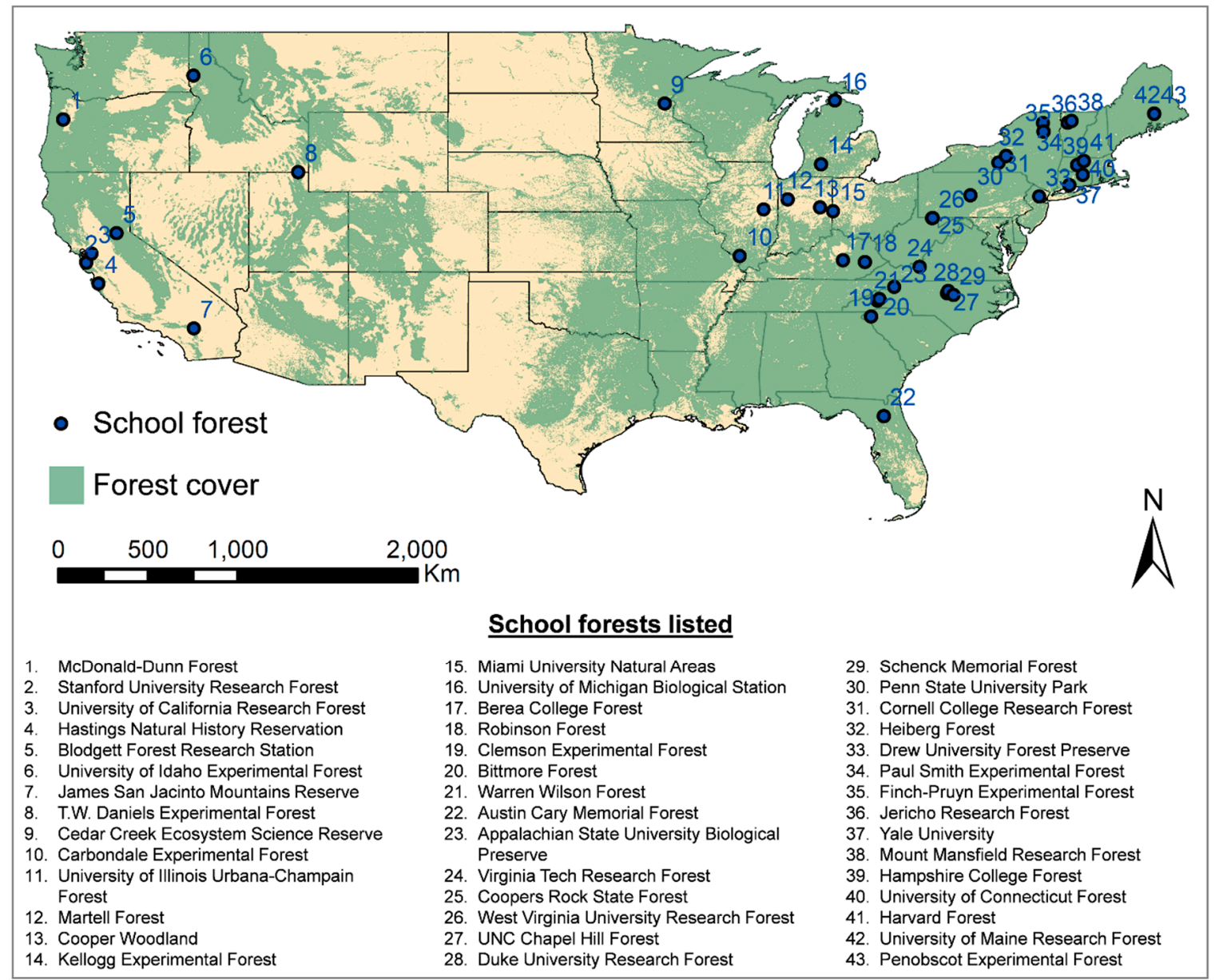

Figure 2. Location and names of forests represented by the works in this review. Names of the forest appear as reported in the works we reviewed. In some cases, forests may have changed names or ownership since publication of the reviewed works (e.g., Cornell College Research Forest, formerly at Cornell University, is now part of the Adirondack Park).

To analyze the works in our sample, we employed a qualitative, interpretivist approach to data analysis and interpretation, which is appropriate for dealing with textual data [39]. Therefore, we believe it is important to defend our choice of epistemology and methods. Intepretivist approaches embrace the subjective interpretation of data [40,41]. Indeed, our qualitative analysis (described below) involved subjective interpretation of concepts described in the works in our sample. Such approaches have been used to conduct similar qualitative literature reviews [42]. Most importantly, an interpretivist epistemology and qualitative methods are well suited for investigating complex, interwoven constructs $[38,40,41]$ and thus our approach was well-matched with our study objectives.

To explore our research question, we utilized a list of a priori codes to review the works in the database [40]. These codes were services included in the Millennium Ecosystem Assessment's lists of provisioning, regulating, supporting, and cultural services [7]. As a group, we added two additional codes: biodiversity and foundational science. Thus the a priori codes were as follows: biodiversity, cultural services, foundational science, provisioning services, regulating services, and supporting services. The final list of codes is outlined in Table 1. We reviewed all the works in the database and assigned one of these codes based on the primary focus of the work. Hereafter, we refer to these codes as "foci" or "focus." Many sources did not explicitly state a focus on a particular ES. Thus, the primary focus of each work was assessed by the member of the research team responsible for reviewing that work. We coded for primary foci, rather than all foci within a given paper, because we wanted to capture the topics that were given considerable attention and not incidental mentions. 
During the review process, we held periodic meetings to compare coding and ensure consistency and validity across the analysis $[40,41,43]$. We additionally noted if works explicitly stated relevance to the follow audiences: IHE administrators, scientists, practitioners, community members, and/or students. Once the review was complete, we performed a review of the coding to ensure inter-author agreement.

Table 1. Foci and definitions used for categorizing works into a typology.

\begin{tabular}{cr}
\hline \multicolumn{1}{c}{ Foci } & Definition \\
\hline Biodiversity & Variety of life in a given ecosystem. \\
\hline Foundational Science & Discovery, testing, or exploration of new phenomena, processes, or technologies. \\
\hline Provisioning Services & Services that result in outputs, such as clean water and food. \\
\hline Regulating Services & Services that govern natural processes, such a regulating climate. \\
\hline Supporting Services & Services that are necessary for all other services, such as nutrient cycling. \\
\hline Cultural Services & Non-material benefits that people get from nature. \\
\hline Aesthetics & Appreciation of the beauty of an ecosystem. \\
\hline Artistic Inspiration & Inspiration from an ecosystem to create art. \\
\hline Bequest & Value of ecosystems for future generations. \\
\hline Cultural Diversity & Reflection of different ways of living and different cultural practices. \\
\hline Cultural Heritage & Connection to traditional places and ways of life. \\
\hline Education & Opportunities for human learning about said ecosystem or about ecological processes. \\
\hline Existence & The satisfying knowledge that a given ecosystem is preserved. \\
\hline Identity & One's understanding of one's self as it relates to the ecosystem. \\
\hline Knowledge Systems & Different ways of knowing, such a traditional ecological knowledge. \\
\hline Recreation & Leisure time spent outdoors. \\
\hline Sense of Place & Deep sense of connection to a given ecosystem or geographic area. \\
\hline Social Capital & Connection to forces larger than oneself. \\
\hline Spirituality & \\
\hline
\end{tabular}

Because CESs are potentially important pathways for relevance, we sought to explore which specific CESs were mentioned within the sample. To conduct this analysis, we uploaded the works identified as discussing a CES focus into NVivo 11 software and qualitatively coded the text based on 10 commonly discussed CESs [12]. The works did not explicitly use the term "cultural ecosystem services" but were clearly discussing ideas that we then categorized as CESs. This analysis allowed us to explore which CESs are being discussed in academic works about school forests.

\section{Results}

We observed unequal distribution of the foci of the works we reviewed (Figure 3). We also observed unequal distribution of the audiences for whom the works had an explicitly stated relevance. The deeper qualitative coding revealed that recreation, education, aesthetics, and sense of place were the only CESs discussed in the works reviewed. We elaborate on each of these findings in the sections below. 


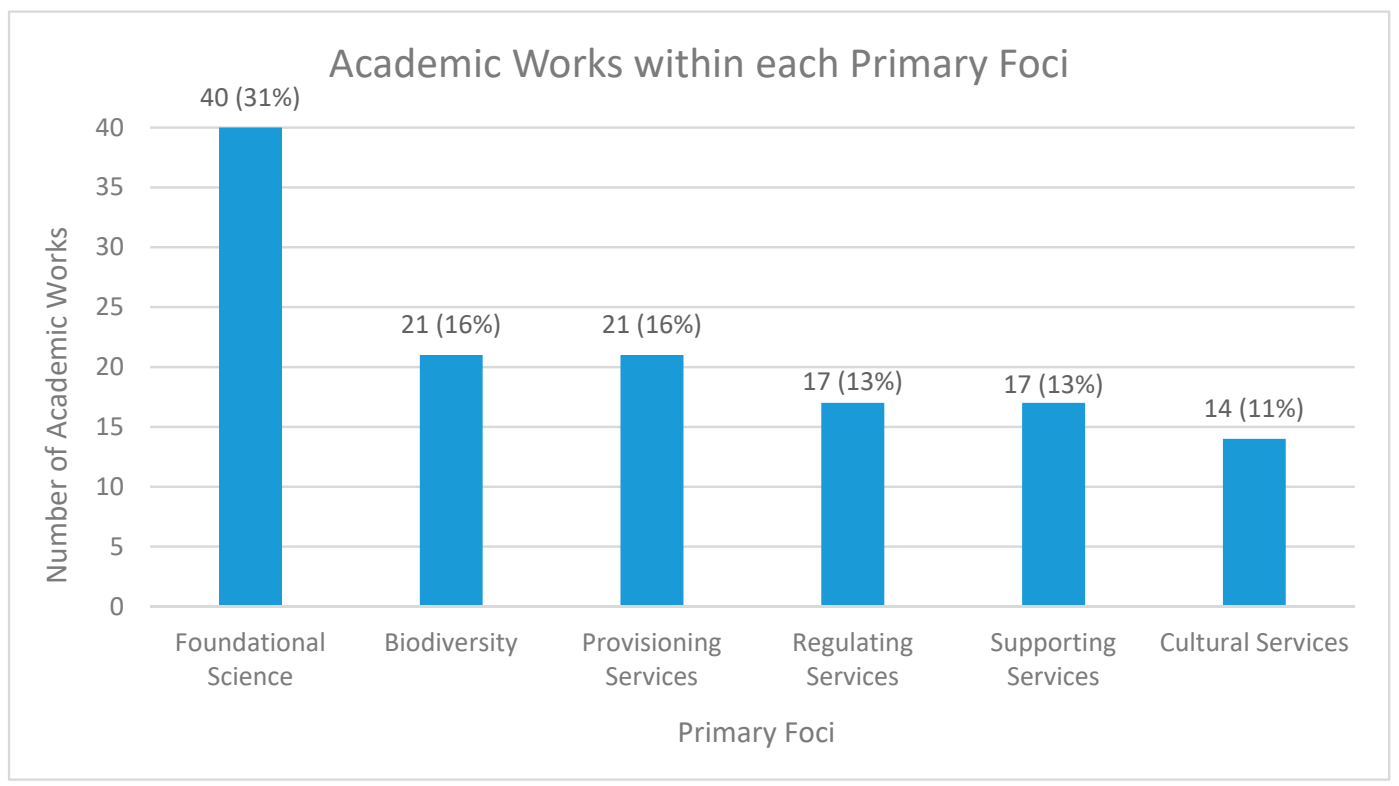

Figure 3. Number and percentage of works within each primary Foci. Foci are mutually exclusive.

\subsection{Foci of the Works}

Forty works ( $31 \%$ of all works reviewed) had a primary focus on foundational science (i.e., physics, chemistry, biology, and mathematics). These works dealt with the discovery, testing, or exploration of new phenomena, processes, or technologies. For example, one journal article in this category [44] investigated the accuracy of global navigation satellite system (GNSS) technology paired with radio frequency (RF) transmission (GNSS-RF). The authors determined that a number of forest characteristics, as well as topography and obstructions, impacted the accuracy of this new technological approach.

Twenty-one works $(16 \%)$ had a primary focus on biodiversity. Works with a primary focus on biodiversity focused on the variety of life within a given ecosystem. One paper, for example, examined the impact of fine woody debris on spider diversity and found that decreases in fine woody debris lead to significant decreases in abundance of spiders, while increases in fine woody debrief shifted the composition of the natural community of spiders [45].

Twenty-one works $(16 \%)$ had a primary focus on provisioning services. These works explored or described ESs that resulted in outputs, such as food, and timber. As an example, one paper explored vegetation response to strip cutting in young hardwood stands. The authors found an increase in both woody and herbaceous biomass within the cut strips [46].

Seventeen works (13\%) focused primarily on regulating services. Works with this focus explored ecosystem services that govern natural process, such as regulating water quality. For example, one paper dealt with the impact of rapid leaf temperature fluctuations on the regulation of isoprene emissions. The researchers found that the temperature of and isoprene emissions within white oak canopies exhibited large short-term variation with changes in solar radiation [47].

Seventeen works (13\%) focused primarily on supporting services. Works in this category dealt with ecosystem services that are necessary for all other services, such as nutrient cycling, habitat provisioning, and primary production. One journal article, for example, looked at habitat provisioning and its impact on bird species abundance. The authors found that bird species abundance was higher in plots with shrubs than those without shrubs [48].

Finally, the focus with the least number of works (14 works, $11 \%$ ) was CESs. Works with a CES focus explored the non-material benefits that people get from ecosystems. As one example, a M.S. thesis explored and described the range of recreational opportunities provided by an urban-proximate forest [49]. The author found that outdoor recreation opportunities strongly correlated with individuals' proximity to the forest as well as with individuals' preferences for different forest management practices. 


\subsection{Relevance to Audiences}

We observed an unequal distribution of the stated audiences within the works reviewed (Table 2). More works stated relevance to practitioners and scientists, while far fewer explicitly discussed implications for community members and students and none of the works stated the relevance of school forests for IHE administrators. Seventy-six (58\%) of the works reviewed explicitly stated that their findings are relevant to practitioners (i.e., foresters, land managers, and other natural resource professionals). Sixty-five (50\%) stated relevance to scientists or broadly to the academic community (including contribution to theory). Only 21 (16\%) stated relevance to community members (including landowners), and even fewer, a total of four works (3\%), stated relevance to students, including K-12 students, college students, and graduate students. Thirty-seven ( $28 \%)$ of the works stated relevance to two audiences (most commonly practitioners and scientists), 12 (9\%) of the works stated relevance to three audiences (most commonly practitioners, scientists, and community members), and two $(<2 \%)$ of the works stated relevance to all four audiences.

Table 2. Number of works that mentions implications for each audience.

\begin{tabular}{ccc}
\hline Audience & Number of Works & Percent of Works ${ }^{\mathbf{1}}$ \\
\hline Practitioners & 76 & $58 \%$ \\
\hline Scientists & 65 & $50 \%$ \\
\hline Community members & 21 & $16 \%$ \\
\hline Students & 4 & $3 \%$ \\
\hline College administrators & 0 & 0 \\
\hline${ }^{1}$ Percentages total greater than $100 \%$, as audiences were not mutually exclusive.
\end{tabular}

\subsection{Cultural Ecosystem Services}

Only 14 works (11\%) focused on cultural services; indeed, it was the foci with the least number of works. Qualitative coding of these works revealed that aesthetics, education, recreation, and sense of place were the only CESs discussed. As examples, one paper focused on aesthetics by exploring scenic preferences of hikers following different forest management practices [50]; another paper focused on community outreach and education through their investigation of the value of forests as the setting for kindergarten learning [51]; a third paper explored recreation options for a school forest [52]; and a fourth paper examined whether and how sense of place was developed in relation to school forests [53]. We did not find any works that focused on artistic inspiration, bequest, cultural diversity, cultural heritage, existence, identity, knowledge systems, social capital, or spirituality.

\section{Discussion}

From their inception, school forests have provided a range of benefits to local communities and beyond. Sustained institutional ownership and management of school forests has contributed to the continued provisioning of biophysical ESs, and has also benefitted generations of scientists, students, and community members. While school forests provide many important benefits to IHEs and local communities, the results from our review suggest that most of the literature omits discussions about education and other non-material benefits, or CESs, that people may receive from school forests. At the same time, most of the academic works $(72 \%)$ do not articulate relevant implications to multiple, diverse audiences.

Our results do not support a conclusion that school forests are not providing CESs. For example, although we did not find any works that reported on the CES of artistic inspiration, several authors of this paper have either taken or taught art courses connected to school forests (e.g., a nature drawing class). The prevalence of writing and artistic retreats/camps in school forests, for example Northland College's Creative Spiritual Forest Retreat [54], also suggests that these are inspirational settings. 
However, these occurrences are typically not reported via academic works that explicitly name school forests. Rather than suggest that school forests do not contribute to artistic inspiration, bequest, cultural diversity, cultural heritage, existence, identify, knowledge systems, social capital, or spirituality, the lack of these CESs in our results is likely a function of two trends. The first trend is the aforementioned tendency for ES scholarship to focus on the biophysical services and give less emphasis to cultural services. Given that this trend is pervasive across conservation research $[9,10]$, it is not surprising that it holds true within works that address or take place at school forests. Research on CESs is growing $[12,55]$ and it is possible the number of works that report on non-material benefits from school forests will increase over time.

A second, potentially concurrent trend may also be responsible for the lack of reported data on CESs and school forests. That is, community members are not engaging with school forests in large numbers, and thus are not receiving many benefits. Academic institutions have long been criticized for being too insular, an "ivory tower" disconnected from the surrounding community [56]. In fact, some school forests are even fenced-off to protect research projects from being tampered with, such as the Fishburn Forest at Virginia Tech. Our review revealed relatively few academic works that explicitly stated relevance to community members. More broadly, it is possible that community members do not always view school forests as available and, subsequently, do not visit, benefit, or connect with them in meaningful ways.

Both trends have potential implications for the long-term protection of school forests. The disproportionately low emphasis on CESs in the academic literature is important in this context, as this lack of emphasis on CESs from school forests may impact the messaging to decision makers. Other scholars have argued that failure to incorporate considerations of CESs can result in problematic natural resource and land-use policy [57-59]. We believe the exclusion of discussions on CESs provided by school forest could impact land use policy at IHEs across the U.S. Such exclusions on a wide scale could play a role in shaping how IHE administrators perceive and value these lands, and how they make decisions about land tenure and management. Of course, not all school forests are equally at risk of sale; indeed, some may even be protected by law or regulation. For example, a portion of the Jericho Research Forest at the University of Vermont is protected by easements initiated by Vermont's land use and development law, Act 250, to conserve deer yards and archeological sites. Nevertheless, if the academic community does not publish about CESs from school forests, IHE administrators may not view school forests as broadly relevant and may be more inclined to sell or develop lands that are not protected.

If diverse audiences do not readily connect with school forests in relevant ways, as suggested by the paucity of academic literature on or mentions of these uses, these areas are at risk for alternate uses that may impact the forests' long-term protection. Whereas the relevance of school forests to forestry education and to the generation of scientific knowledge may be valued within forestry departments (primarily through faculty and graduate student research), the relevance of these areas to additional audiences appears more tenuous. When neighbors view school forests as "public assets" [1] (p. 55), they may be more likely to speak out if these areas are put on the chopping block. If it is indeed true that local community members are not engaging with school forests, they may be less likely to protest if and when school forests are considered for sale or development.

Given our results and the possible trends that explain them, we see several opportunities to increase relevance. We suggest each of these opportunities could be institutionalized as formal campus policy, but we also urge scholars and land managers to consider adopting these suggestions regardless of formal policy change. First, our results reveal an opportunity for scholars to investigate more intentionally the CESs that school forests provide. School forests have long served as laboratories for biophysical research, but they also hold potential to support social science investigations. Scholars interested in CESs should consider exploring new and innovative research questions using school forests as the research setting. This would expand the range of research taking place at school forests, making the forests relevant to a wider range of scholars. It would also diversify the scholarship associated with 
school forests, thus contributing to both messaging about CESs from school forests and the literature on CESs more broadly. We recognize that the focus of research happening at school forests may be driven, at least in part, by funding. Nevertheless, we encourage other researchers and scholars to consider publishing on the non-material benefits from school forests. Publishing would support CES scholarship and increase the perceived relevance of these lands, thereby protecting them from risk of sale or development.

We also suggest that managers of school forests should engage local community members directly to increase the perceived relevance on these areas. Many, if not most, school forests host demonstration activities designed to share new forestry techniques or emerging science with forest landowners and forestry professionals $[1,16]$. We applaud these efforts and encourage managers of school forests to continue or potentially expand their efforts in this area (i.e., building broad relevance). At the same time, we also suggest that managers consider public interests regarding management decisions. We make this recommendation because when school forests are used by community members, those community members might develop a vested interest in these areas and come to view them as public assets (i.e., building deep relevance); this is likely what ultimately drives advocacy for the protecting these areas [1]. We urge managers to consider the ESs that are important to community members when making management decisions on school forests. In particular, CESs should factor into decision making, as omitting them could result in decisions and plans of limited relevance [11]. Incorporating considerations of community members and the CESs that they derive from school forests into management plans will help build relevance across general and priority audiences [33,34]. For example, explicitly considering the CES of artistic inspiration in school forest plans could facilitate broad connections and community pride across local residents and deep connections to science, technology, engineering, arts, and mathematics (STEAM) investigations possible in these places by local school and youth groups. Thus, managers of school forests should continue outreach to community members while thinking about forest planning with that stakeholder group in mind.

Finally, students are yet another population of individuals for whom relevance could be emphasized. Despite education being a major ES associated with school forests, very few of the works reviewed articulated relevance to education. This may be somewhat expected, as most did not focus specifically on forestry education. Nonetheless, we suggest that forestry programs think critically about designing educational connections to and within school forests. As noted by O'Hara and Salwasser [6] (p. 581):

Forestry is now focused on ecosystems that are analyzed at multiple spatial scales to produce a wide range of ecosystem benefits. Forest science education must embrace these ongoing changes into the curricula and be inclusive of the broader range of faculty expertise needed to encompass the rapidly evolving character of contemporary forestry.

Thus, forestry education curricula would do well to increase their focus on cultural as well as biophysical services, and we suggest school forests provide an opportunity to explore the full range of ESs. As relevant connections are both personal and place-based, education professionals should emphasize the uniqueness of the school forest(s) in their area and encourage students to draw multiple connections to these forests that resonate with their own experiences. This would encourage yet another potential stakeholder group to advocate for school forests if they are at risk of sale or development, and prime future forestry professionals and scientists about the important role of CESs from forests and school forests in particular.

The strategies outlined above will be useful for those working at school forests in the U.S. and beyond. They may be equally useful to managers of forested parks and protected areas outside the realm of school forests. Numerous studies have identified that the major drivers of forest loss and fragmentation are rooted in socioeconomic considerations [60,61]. We argue that CESs could factor into such consideration; if decision makers view forests as providing CESs, they may perceive them as valuable and worth conserving. Thus, increasing the knowledge about CESs provided by forests may increase relevance and, subsequently, increase support for ongoing conservation and protection of areas at risk for sale or development. 


\section{Limitations}

Our methods prioritized academic works that explicitly named a school forest as either the location of their research or the focus of it. There are surely numerous studies that took place at school forests but were excluded by our search terms because they did not explicitly name a school forest. Indeed, there is a number of colleges and universities within the U.S. that own forests but that did not emerge via our search. Some of these institutions are home to well-known and well-established schools of forestry, such as the University of Washington. It is possible this is due to common conventions regarding explicitly naming research sites; some investigators might not feel explicit naming is necessary, particularly if there are many sites. Regardless, of why certain schools did not appear in our search, there are surely many additional works that exist but were not captured in our database because, although they report on research conducted in school forests, they did not identify these forests. This means the number of works included in our database is almost certainly a low estimate of all the possible works that could have been included.

Understanding all the research, teaching, and outreach occurring in school forests in the U.S. would require a greater level of inquiry than we had capacity for (interviews or surveys with faculty, forest managers, and other users; course syllabi; management plans; interviews or surveys with community members; etc.). Because collecting that information for each school forest represented such an undertaking, we focused our efforts on literature to understand what messages are being conveyed via the published research that reports on school forests.

It is important to note that the lack of CESs in the literature likely does not accurately reflect the true efforts to integrate school forests into the social fabric of the larger community. Yet, it does impact the messages that are conveyed about these locations. Finally, examinations of works outside of the target databases (e.g., IHE websites, school forest management plans) were outside of the scope of this investigation. These other sources warrant further study to examine whether patterns of foci and audiences of relevance identified here transcend the boundaries of our investigation.

\section{Conclusions}

We argue that the value and relevance of school forests must be clearly articulated to both members of surrounding communities and to IHE administrators. This articulation should occur in addition to maintaining current audiences of scientists and practitioners. If IHE administrators do not see the value of school forests, they may be more likely to look at these forests for development potential and revenue generation via harvesting at the expense of other benefits. Similarly, if community members do not see school forests as valuable and relevant, they may be less likely to fight to protect these areas when they are considered for development. We offer a simple call to action for authors across disciplines: specify the forest in which your study is based in your publications. Many investigations in school forests may not have been captured in this review simply because of an aversion to naming study sites. We challenge researchers to more explicitly name locations, at least to the town and forest level, so that the work being conducted in those school forests can be better highlighted and connected to receptive audiences. IHEs should also consider instituting policies to address this; much in the same way that investigators are required to disclose their funding sources, researchers could be required to explicitly name their research sites. This could impact relevance, as the tendency to exclude particular site names to lend a greater perception of generalizability (especially in the natural sciences) undervalues the impact that naming may have on building connections, stewardship, and advocacy with multiple audiences.

Author Contributions: Conceptualization, K.J.C., E.E.P., and K.F.W.; methodology, K.J.C. and E.E.P.; software, K.J.C.; validation, E.E.P., T.M.G., D.T., and P.W.C.; formal analysis, K.J.C., E.E.P., T.M.G., D.T., and P.W.C.; data curation, K.J.C., E.E.P., T.M.G., D.T., P.W.C., R.E.T.J., K.F.W., and W.S.K.; writing-original draft preparation, K.J.C.; writing-review and editing, E.E.P., T.M.G., D.T., and W.S.K.; visualization, E.E.P. and D.T.; project administration, K.J.C.; funding acquisition, K.F.W. All authors have read and agreed to the published version of the manuscript. 
Funding: This work was supported by the U.S. Department of Agriculture National Institute of Food and Agriculture, McIntire-Stennis project 1003495.

Acknowledgments: We are grateful to Rachelle Gould for her feedback on earlier drafts of this manuscript.

Conflicts of Interest: The authors declare no conflict of interest. The funders had no role in the design of the study; in the collection, analyses, or interpretation of data; in the writing of the manuscript, or in the decision to publish the results.

\section{References}

1. Straka, T.J. Public outcry increasingly becoming safeguard of university forests: College-owned lands are morphing from educational, research, and outreach assets into financial assets. Plan. High. Educ. 2010, 38, 52-60.

2. Pitkin, F.H.; Ehrenreich, J.H. The University of Idaho University Forest: A forest dedicated to student education, research and training. Univ. Ida. For. Wildl. Range Exp. Stn. 1977, 77, 1-24.

3. Forrer, K. Integrating Sustainability into Forest Management Planning of the University of Vermont's Jericho Research Forest, Jericho, VT. Master's Thesis, University of Vermont, Burlington, VT, USA, 2005.

4. Seiler, J. The History of a Proposed Indoor Training Facility and Stadium Woods. Available online: https://vtechworks.lib.vt.edu/bitstream/handle/10919/64415/History-ProposedIndoorTrainingFacilitySeiler2012.pdf?sequence=1 (accessed on 12 July 2018).

5. Van Der Werf, M. The almighty sawbuck: Colleges struggle to balance interests over their forested lands. Chron. High. Educ. 2000, 47, 36-38.

6. O’Hara, K.L.; Salwasser, H. Forest science education in research universities. J. For. 2015, 113, 581-584. [CrossRef]

7. MA Board. Millennium Ecosystem Assessment; Island Press: Washington, DC, USA, 2005.

8. Daily, G.C. Ecosystems's Services: Societal Dependence on Natural Ecosystems; Island Press: Washington, DC, USA, 1997.

9. Benayas, J.M.R.; Newton, A.C.; Diaz, A.; Bullock, J.M. Enhancement of biodiversity and ecosystem services by ecological restoration: A meta-analysis. Science 2009, 325, 1121-1124. [CrossRef]

10. Thom, D.; Seidl, R. Natural disturbance impacts on ecosystem services and biodiversity in temperate and boreal forests. Biol. Rev. 2016, 91, 760-781.

11. Chan, K.; Goldstein, J.; Satterfield, T.; Hannahs, N.; Kikiloi, K.; Naidoo, R.; Vadeboncoeur, N.; Wooside, U. Cultural services and non-use values. In Natural Capital: Theory and Practice of Mapping Ecosystem Services; Kareiva, P., Polasky, S., Tallis, H., Ricketts, H., Daily, G., Eds.; Oxford Univesity Press: Oxford, UK, 2001; pp. 206-288.

12. Gould, R.K.; Lincoln, N. Expanding the suite of Cultural Ecosystem Services to include ingenuity, perspective, and life teaching. Ecosyst. Serv. 2017, 25, 117-127. [CrossRef]

13. Fernow, B.E. The New York state college of forestry. Science 1898, 8, 494-501. [CrossRef]

14. New York State Archives. New York state college of forestry pamphlets. Available online: https://archive.is/ 20110722141054/http://iarchives.nysed.gov/xtf/view?docId=20-1-401.xml (accessed on 6 July 2018).

15. Anonymous. An expert opinion on the Cornell University Forest experiment. J. For. 1905, 3, 32-38.

16. Burkhardt, C.E.; Straka, T.J.; Bullard, S.H. Forestland controlled by schools of forestry: Characteristics and Management. J. For. 1988, 86, 39-42.

17. Harvard Forest History. Available online: http://harvardforest.fas.harvard.edu/history (accessed on 11 July 2018).

18. Barr, P.M. The research program of Blodgett Forest of the University of California. J. For. 1946, 44, 738-741.

19. Raup, H.M. Old field forests of southeastern New England. J. Arnold Arbor. 1940, 21, 266-273.

20. Cline, A.C. The restoration of watershed forests in the hurricane area. J. N. Engl. Water Work. Assoc. 1939, 53, 223-235.

21. Ford, S.E.; Keeton, W.S. Enhanced carbon storage through management for old-growth characteristics in northern hardwoods. Ecosphere 2017, 8, 1-20. [CrossRef]

22. Muller, R.N.; Maehr, D.S. Are universities leaders in the stewardship of conservation lands? Bioscience 2000, 50, 707-712. [CrossRef]

23. Eagles, P.F.J. Research priorities in park tourism. J. Sustain. Tour. 2014, 22, 528-549. [CrossRef] 
24. Jarvis, J. The Relevance of National Parks. In Proceedings of the George Wright Society Conference on Parks; Bardenhagen, E., Ed.; Protected Areas, and Cultural Sites: New Orleans, LA, USA, 2012.

25. Keiter, R.B. The National Park System: Visions for Tomorrow. Nat. Resour. J. 2010, 50, 71-110.

26. NPS Stewardship Institute. Urban Agenda: Call to Action Initiative. Available online: http://www.nps.gov/ subjects/urban/Urban-Agenda.htm (accessed on 4 April 2019).

27. McCown, R.S.; Laven, D.; Manning, R.; Mitchell, N. Engaging new and diverse audiences in the National Parks: An exploratory study of current knowledge and learning needs. George Wright Forum. 2012, 29, 272-284.

28. Perry, E.E.; Xiao, X.; Manning, R. Barrier or bridge? The role of transportation in national park visitation by racial and ethnic groups. World Leis. J. 2015, 57, 1-12. [CrossRef]

29. Simon, N. The Art of Relevance; Museum 2.0: Santa Cruz, Spain, 2016.

30. Byrne, J.; Wolch, J.; Zhang, J. Planning for environmental justice in an urban national park. J. Environ. Plan. Man. 2009, 52, 365-392. [CrossRef]

31. Kyle, G.T.; Mowen, A.J.; Tarrant, M. Linking place preferences with place meaning: An examination of the relationship between place motivation and place attachment. J. Environ. Psych. 2004, 24, 439-454. [CrossRef]

32. Watts, G.; Miah, A.; Pheasant, R. Tranquillity and soundscapes in urban green spaces-predicted and actual assessments from a questionnaire survey. Environ. Plan. B 2013, 40, 170-181. [CrossRef]

33. Gorayska, B.; Lindsay, R. The roots of relevance. J. Pragmat. 1993, 19, 301-323. [CrossRef]

34. Henderson, K.A.; Walker, G.J. Ethnic and racial research methods. In Race, Ethnicity, and Leisure: Perspectives on Research, Theory, and Practice; Stodolska, M., Shinew, K.J., Floyd, M.F., Walker, G.J., Eds.; Human Kinetics: Champaign, IL, USA, 2014; pp. 21-36.

35. Plieninger, T.; Bieling, C.; Fagerholm, N.; Byg, A.; Hartel, T.; Hurley, P.; López-Santiago, C.A.; Nagabhatla, N.; Oteros-Rozas, E.; Raymond, C.M.; et al. The role of cultural ecosystem services in landscape management and planning. Curr. Opin. Env. Sust. 2015, 14, 28-33. [CrossRef]

36. Moher, D.; Liberati, A.; Tetzlaff, J.; Altman, D.G.; PRISMA Group. Preferred reporting items for systematic reviews and meta-analyses: The PRISMA Statement. PLoS Med. 2009, 6, e1000097. [CrossRef]

37. Nakagawa, S.; Noble, D.W.A.; Senior, A.M.; Lagisz, M. Meta-evaluation of meta-analysis: Ten appraisal questions for biologists. BMC Biol. 2017, 15,1-14. [CrossRef]

38. Pickering, C.M.; Byrne, J. The benefits of publishing systematic quantitative literature reviews for PhD candidates and other early career researchers. High. Educ. Res. Dev. 2014, 33, 534-548. [CrossRef]

39. Glaser, B.G.; Strauss, A.L. The Discovery of Grounded Theory: Strategies for Qualitative Research; Routledge: New York, NY, USA, 1967.

40. Glesne, C. Becoming Qualitative Researchers: An Introduction; Addison Wesley Longman: New York, NY, USA, 1999.

41. Patton, M.Q. Qualitative Research and Evaluation Methods, 3rd ed.; Sage Publishing: Thousand Oaks, CA, USA, 2002.

42. Gould, R.K.; Coleman, K.; Gluck, S.B. Exploring dynamism of cultural ecosystems services through a review of environmental education research. AMBIO 2018, 47, 869-883. [CrossRef]

43. Saldana, J. The Coding Manual for Qualitative Researchers, 2nd ed.; Sage Publishing: Los Angeles, CA, USA, 2013.

44. Zimbelman, E.G.; Keefe, R.F. Real-time positioning in logging: Effects of forest stand characteristics, topography, and line-of-sight obstructions on GNSS-RF transponder accuracy and radio signal propagation. PLoS ONE 2018, 13, e0191017. [CrossRef]

45. Castro, A.; Wise, D.H. Influence of fine woody debris on spider diversity and community structure in forest leaf litter. Biodivers. Conserv. 2009, 18, 3705-3731. [CrossRef]

46. Martin, A.; Schuler, J.L.; Edwards, J. Vegetation response to strip cutting young hardwood stands in West Virginia. J. Sustain. Forest. 2017, 36, 818-832. [CrossRef]

47. Singsaas, E.L.; Sharkey, T.D. The regulation of isoprene emission responses to rapid leaf temperature fluctuations. Plant. Cell Environ. 1998, 21, 1181-1188. [CrossRef]

48. Zebehazy, L.A.; Rossell, C.R., Jr. Winter bird use of eastern white pine (Pinus strobus) stands with different structural characteristics. J. Elisha Mitch. Sci. Soc. 1996, 112, 94-97.

49. Finley, M.T. McDonald Forest: A Case Study in the Use of the Recreation Opportunity Spectrum Planning Framework in a Near-urban Forest. Master's Thesis, Oregon State University, Corvallis, OR, USA, 1990.

50. Shelby, B.; Thompson, J.; Brunson, M.; Johnson, R. Changes in scenic quality after harvest: A decade of ratings for six silviculture treatments. J. For. 2003, 101, 30-35. 
51. Latomme, A.; Rosenblatt-Naderi, J. Into the Woods: A Study Exposing Children to Outdoor Classrooms. Available online: http://thecela.org/wp-content/uploads/INTO-THE-WOODS.pdf (accessed on 16 July 2018).

52. Miller, A.; Matisoff, C.; McFadden, K.; LaGuardia, C.; Leung, Y.F. Towards Development of a Sustainable Recreation Strategy for University Forests: A Southeastern U.S. Example. In Proceedings of the 2011 and 2012 Southeastern Recreation Research Conference, Appalachian State University, Boone, NC, USA, 9-12 May 2012.

53. Gough, D.B. The Value of the Commonwealth: An Ecocritical History of Robinson Forest. Ph.D. Thesis, University of Iowa, Iowa City, IA, USA, 2013.

54. Northland College. Creative and Spiritual Forest Retreat. Available online: https://www.northland.edu/ event/creative-spiritual-retreat/ (accessed on 4 April 2019).

55. Milcu, A.; Hanspach, J.; Abson, D.; Fischer, J. Cultural ecosystem services: A literature review and prospects for future research. Ecol. Soc. 2013, 18, 1-34. [CrossRef]

56. Kezar, A.; Chambers, A.C.; Burkhardt, J.C. Higher Education for the Public Good: Emerging Voices from a National Movement; Jossey-Bass: San Francisco, CA, USA, 2015.

57. Adams, A.; Morse, J. Non-material matters: A call for integrated assessment of benefits from ecosystems in research and policy. Land Use Policy 2019, 80, 400-402. [CrossRef]

58. Müller, S.M.; Peisker, J.; Bieling, C.; Linnemann, K.; Reidl, K.; Schmieder, K. The importance of cultural ecosystem services and biodiversity for landscape visitors in the biosphere reserve Swabian Alb (Germany). Sustainability 2019, 11, 2650. [CrossRef]

59. Riechers, M.; Strack, M.; Barkmann, J.; Tscharntke, T. Cultural ecosystem services provided by urban green change along an urban-periurban gradient. Sustainability 2019, 11, 645. [CrossRef]

60. Alix-Garcia, J.; Munteanu, C.; Zhao, N.; Potapov, P.V.; Prishchepov, A.V.; Radeloff, V.C.; Bragina, E. Drivers of forest cover change in Eastern Europe and European Russia, 1985-2012. Land Use Policy 2016, 59, $284-297$. [CrossRef]

61. Liu, Y.; Feng, Y.; Zhao, Z.; Zhang, Q.; Su, S. Socioeconomic drivers of forest loss and fragmentation: A comparison between different land use planning schemes and policy implications. Land Use Policy 2016, 54, 58-68. [CrossRef]

(C) 2020 by the authors. Licensee MDPI, Basel, Switzerland. This article is an open access article distributed under the terms and conditions of the Creative Commons Attribution (CC BY) license (http://creativecommons.org/licenses/by/4.0/). 